\title{
The regulation of patrimony within civil law systems: from a unitary to a divisional approach in the management of patrimonial assets and its effects on private international law rules
}

\author{
Giulio Peroni*
}

\begin{abstract}
Private International Law (PIL) does not admit patrimony, usually considered as the totality of the property rights of a person, as an autonomous legal category. Whereas, within civil law systems influenced by Roman Law, at the domestic or internal level, patrimony is a recognised legal concept. But, actually, this unitary vision seems less and less stable owing to the adoption, within said systems, of some types of negotiable instruments that are able to realise different forms of patrimonies. This article intends to underline how civl law systems are gradually affirming a divisional approach about the regulation of patrimony, as traditionally happens at the level of PIL rules. But at the same time, it aims at highlighting how, in particular, by recourse to the use of trusts, it is possible to recover both at the PIL and internal levels a unitary vision.
\end{abstract}

Keywords: Patrimony; Roman Law: civl law systems; Unitary approach; Divisional approach; Trusts

\section{A. Introduction}

Patrimony is usually considered as the set of legal relations (assets and liabilities) of economic relevance belonging to a specific person or entity; it is not regarded by Private International Law (PIL) as an autonomous category, neither is it a criterion directed to solve the typical questions of conflict of laws concerning applicable law and jurisdiction. For this reason, at PIL level, the regulation of patrimony generally coincides with that of its individual assets: property, immovables, movables, contracts, torts, credits and debts. This is a direct consequence of the fact that, within the different national legal systems, legislators usually do

\footnotetext{
* Associate Professor in International Law at the School of Law of the University of Milan. Email: giulio.peroni@unimi.it.
} 
not value patrimony as a legal category ${ }^{1}$ but rather as a system category, as happens, for example, in other typical legal expressions such as good faith and public policy ${ }^{2}$ in respect to which the legislator does not provide a definition, preferring, on the contrary, to leave this task to the courts and legal scholars.

It was, above all, the doctrine of civil law systems to worry about reconstructing the patrimonial phenomenon, according to a unitary vision, for which patrimony was seen essentially as a manifestation of the legal personality of every legal subject in the world of economic relations. In this way, in each civil law system, there has been an identification of patrimony with the person of its holder, with the clear purpose to give a unitary regulation to the patrimonial assets of a person. Nevertheless, this approach has influenced the functioning of certain PIL rules, albeit limited to the sectors of succession and insolvency. In the first case, submitting succession issues to the national law or domicile of the deceased; in the second case, the location of the centre of the debtor's main interests are usually linked to its 'headquarters'.

But, the aforesaid unitary vision seems actually less and less stable due mainly to the rise of the phenomenon of economic and trade globalisation ${ }^{3}$ and of Europeanisation of PIL $^{4}$ that

${ }^{1}$ Legal categories are usually central to legal reasoning. It is very difficult to imagine legal reasoning without the use of categories. Categorical thinking usually affects every area of law. See S A Alexander, "The Transformation of Trust as a Legal Category, 1800-1914" (1987) Law and History Review 303.

${ }^{2}$ Good faith and public policy are abstract and comprehensive terms used in many areas of the law. Good faith encompass a sincere belief or motive without any malice or the desire to defraud others while public policy are rules with different sources from which parties have no freedom to derogate. They are either created by States unilaterally to protect the fundamental values of their society, or they are created at the regional level, or even at an international-multilateral level.

${ }^{3}$ See JH Dunning, Globalization of Firms and the Competitiveness of Nations (Lund University Press, 1990); M Baldassarri, L Paganetto, E S Phelps (eds) International Differences in Growth Rates: Market Globalization and Economic Areas (Palgrave Mac Millan, 1994); K Lynch, The Forces of Economic Globalization: Challenges to the Regime of International Commercial Arbitration (Kluwer, 2003); T Berend, An Economic History TwentiethCentury Europe: Economic Regimes from Laissez-Faire to Globalization (Cambridge University Press, 2006); D Rodrick, One Economics, Many Recipes: Globalization, Institutions and Economic Growth, (Princeton University Press, 2007); D Schneiderman, Constitutionalizing Economic Globalization: Investments Rules and Democracy's Promise (Cambridge University Press, 2008).

${ }^{4}$ It is known that the 1997 Treaty of Amsterdam substantially and controversially changed the EC Treaty and the changes that affected the field of PIL are known as "The Europeanisation of PIL". This phenomenon can be seen as a process whereby the European Community and now the European Union has been given legislative powers to create PIL rules through Art 81 TFEU (ex Art 65 TEC). This concerns jurisdiction, recognition and enforcement of judgments and rules of applicable law; in short all PIL traits. For further details see J Basedow, "The Communitarization of the Conflict of Laws under The Treaty of Amsterdam" (2000) 37 Common Market Law Review 687; P Pocar, "La comunitarizzazione del diritto internazionale privato: una 'European Conflict of Laws Revolution'?” (2000) 36 Rivista di diritto internazionale privato e processuale 873; A Bonomi, "Il diritto internazionale privato dell'Unione europea: considerazioni generali, in A Bonomi (ed), Diritto internazionale e cooperazione giudiziaria in materia civile (Giappichelli, 2009) 1; V Van Den Eeckout, "The Instrumentalisation of Private International Law - Quo Vadis? Rethinking the 'Neutrality' of Private International Law in an Era of 
has given a great impulse to the growing of the so-called Market of legal rules ${ }^{5}$ for which every legal system produces different legal techniques for the solution of a given problem and within the said market the law suppliers can meet the need of the law consumers.

States, in order to attract more foreign investors and to avoid capital flight and the migration of its own entrepreneurs to other countries (normally, characterised by lower labour costs and taxes), often open their legal systems to legal values and principles and to new types of negotiable instruments developed elsewhere. In this way, they try to adapt themselves to the requirements of market players. It is the case that many EU civil law countries have introduced, over time, ideas from common law countries into their legal systems eg new forms of contracts, like leasing, factoring, joint venture and project financing, ${ }^{6}$ and legal institutions, like trusts, hitherto unknown to their culture and belonging to that other most important legal tradition in the world.

Particularly, thanks to the influence exercised by trusts within civil law systems in recent years, a more widespread variety of negotiable instruments have been introduced, like the Italian atto di destinazione, the Spanish acto costitutivo del par las personas con discapacidad, the French contrat de confiance, and San Marino's contratto di affidamento fiduciario (see infra). Thus, we observe within the EU continental systems the increase in a different perspective in the management of patrimony, more precisely: a divisional approach, for which diverse property rights, belonging to the patrimony of the same physical or legal person, can be separated from each other, to satisfy different economic purposes of their owner, considered worthy of protection by the relevant national legal order. In other words, there is the creation of different forms of patrimonies potentially submitted to distinct legal

Globalisation and Europeanisation of Private International Law", in J S Bergé, S Franco and M Gardenes Santiago (eds), Boundaries of European Private International Law (Bruylant 2015) 387.

5 See R A Posner, "Creating A Legal Framework for Economic Development" (1998) 13 The World Bank Observer 3; U Mattei, "Efficiency in Legal Transplants: An Essay in Comparative Law and Economics" (1994) 3 International Review of Law and Economics 12; S Woolcock, The Single European Market: Centralization or Competition among National Rules? (Royal Institute of International Affairs, 1994); HW Sinn, Competition between Competition Rules, (1999) 7273 National Bureau of Economic Research Working Paper 2-36; W Andy, "Public Sector Accounting-Democrat Accountability or Market Rules?" (2004) 24 Public Money and Management 5; R Cotter, Il mercato delle regole, (Il Mulino, 2006).

${ }^{6}$ An important role concerning the diffusion of leasing and factoring, that had their origins in the Anglo Saxon systems, was played by the Unidroit Convention on international leasing and on factoring (Ottawa, 28 May 1988). For comment see H Rosen, Leasing Law in the European Community (Euromoney Publications PLC,1991); A Knebel, Der Aufwendungsersatzanspruch des Leasinggebers nach der Unidroit-Leasing Konvention (Peter Lang, 1994); F Ferrari, Il factoring internazionale: commento alla convenzione uniudroit sul factoring internazionale (Cedam, 1999); D Leistner and A Barbara, Internationales Factoringeine rechtsvergleichende Darstellung zum Recht der Bundesrepublik Deutschland, Frankreichs und der Vereinigten Staaten unter Einschluss der UNIDROIT-Konvention uber das Internationale Factoring (1988): mit Vertragsmustern, FCI-Vorschriften und dem Text des Ubereinkommens vom 28 Mai 1988, (C.H. Beck, 1992). 
disciplines at an internal level, rather than the whole patrimony being treated in the same way.

Thus, in civil law systems, the establishment of the divisional approach about the management of patrimony, characterises not only the functioning of their PIL rules (with the exception, before cited, of succession and insolvency), but above all of their substantive rules. However, in the PIL case, the divisional approach consists of breaking patrimony up into its components, recognising each of them as a specific discipline with their own connecting factors (such as the situs of the immovable property or the place where the contract is made or the place where a tort is committed); on the contrary, at an internal level, the divisional approach consists of establishing various pools of patrimonial assets, each one devoted to realising different aims and to guaranteeing special categories of creditors.

In addition, it is important to underline that the possibility of submitting patrimony in some civil law systems (at PIL and internal level) to a unitary solution is not excluded thanks to the recourse to the legal institution of a trust. This institution was unknown in civil law systems until the entry into force of the Hague Convention of 1985 on the law applicable to trusts and on their recognition. ${ }^{7}$ The conflict rules contained in that international instrument have the primary purpose of enabling the recognition of the trust and its legal effects within each Contracting State, if the trust has been constituted under the law of a State which admits it and to which the settlor has made reference in the corresponding constituting act.

Particularly, the Hague Convention allows the settlor to put all his patrimonial assets in a trust which is subject to one law only (see Articles 6-8). So, that instrument could appear to be the tool to recover both at internal and PIL level, as we will see infra, a unitary management of patrimony, in a historical moment characterised by the rise of different figures of patrimonial assets.

\section{B. Patrimony in private international law}

\footnotetext{
${ }^{7}$ Concluded on 1 July 1985. Entry in force on 1 January 1992. The full text of the convention is available at the web site of the Hague Conference at the page http://www.hcch.net/index en.php? act=conventions.text\&cid=59 (accessed on 12 June 2017). The Convention is in force for 14 States including the following civil law States: Italy, Liechtenstein, Luxembourg, Monaco, Netherlands, Panama and Switzerland, see https:/www.hcch.net/en/instruments/conventions/status-table/?cid=59 accessed 25 July 2018. For an analytical comment see A E von Overbeck, Explanatory Report on the 1985 Hague Trusts Convention (HCCH Publications, 1985) and HCCH, Proceedings of the Fifteenth Session (1984)-Trusts, Applicable Law and Recognition (HCCH Publications 1985); J Harris, The Hague Trusts Convention: Scope, Application and Preliminary Issues (Hart, 2002); L Fumagalli, La Convenzione dell'Aja sul trust e il diritto internazionale privato italiano (1992) 42 Diritto del Commercio Internazionale 533; F Albissini, R Gambino, "The Italian Civil Law System and The Hague Convention on Trust" (1993) 2 Journal of International Trust and Corporate Planning 73; J P Beraudo, "La convention de la Haye du 1er juillet 1985 relative à la loi applicable au trust et à sa reconnaissance” (1985-1986) Travaux du comité francais de droit international privé 21.
} 
Private International Law (PIL) is usually considered that part of a national legal system which comes into operation when a court is faced with a claim that contains a foreign element. It is only when this factor is present, that PIL has a function to perform. Firstly, to fix the conditions under which the court is competent to entertain such a claim. Secondly, to establish for each class of cases the specific system of law by reference to which the rights of the parties must be determined. Thirdly, to specify the circumstances in which a foreign judgment can be recognised as decisive in the question in dispute and the right vested in the judgment creditor by a foreign judgment can be enforced by action in a specific country.

As regards patrimony, we have already noted how it is not usually considered by PIL to be an autonomous legal category nor a legal criterion directed to solve problems of conflict of laws. This is likely due, on the one hand, to the lack of a definition of patrimony and, on the other hand, to the natural variability of its composition as regards quantitative and qualitative assets during the lifetime of its owner. Thus, PIL traditionally prefers to break patrimony down into its basic components: property, immovables, movables, contracts, torts, credits and debts. In this way, each of these elements is submitted to a specific applicable law and, perhaps is the subject of a special jurisdiction rule. It follows further that we may have different patrimonial assets each one submitted to a different applicable law. So, it is impossible to discuss, prima facie, about a law and a forum of patrimony taken as a whole. Therefore, as patrimony is not inserted into the group of legal categories directly considered by PIL, the traditional problem of characterisation does not arise. ${ }^{8}$

In contrast, from the point of view of substantive law, in civil legal systems, scholars have been discussing for a long time the legal nature of patrimony and its functions. Essentially, under those systems, two different positions can be identified: the subjective ${ }^{9}$ and the

${ }^{8}$ The question of characterisation, sometimes referred to in English as "classification" (Beckett was the first to suggest that classification was linguistically a better term in English than qualification, see "The Question of Classification Qualification in Private International Law" (1934) 15 British Yearbook of International Law 46) of the cause of action, means the allocation of the question raised by the factual situation before the court to its legal category. Its object is to reveal the relevant rule for the choice of law. The rules of any given system of law are arranged under different categories some being concerned with status, others with succession, procedure, contract, tort and so on and until a judge, faced with a case involving a foreign element has determined the particular category into which the question before him falls, he can make no progress for he will not know what choice of law rule to apply. He must discover the true basis of the claim being made.

9 See C Aubry and C Rau, Cours de droit civil francais (Marchal et Billard, 1839); P Cazelles, De l'ideè de continuation de la personne comme principe des transmissions universelles (Rosseau, 1905); F S Bianchi, Corso di diritto civile (Turin, 1886) 3-15; G Bonelli, La teoria della persona giuridica (1910) 2 Rivista di diritto civile 498, 614; H Gazin, Essai critique sur la notion de patrimoine dans la doctrine classique (Rosseau, 1910); J P Vershave, Essai sur le principe de l'unitè du patrimoine (Anrt, 1985) 190; G Ripert, Les forces creatrices du 
objective theory. ${ }^{10}$

For the first opinion, patrimony must be considered only as a unique and unitary entity, coinciding with the person of its holder. For the second, patrimony is a legal unitary entity able, on the one hand, to be submitted to property or other right and, on the other hand, to be transferred by inter vivos and mortis causa negotiable instruments. Under both doctrinal positions patrimony essentially is aimed at guaranteeing the creditors of its holder.

However, as we will see, due to the introduction of new forms of contracts and other negotiable instruments in some continental European countries (above all in Spain, Italy and France), a dynamic approach has emerged that is able to break down patrimony into different patrimonial assets, each one submitted to different regulations. It is the case of the cited contrat de fiducie ${ }^{11}$ introduced into the French civil code in 2007 or patrimonio di destinazione $^{12}$ inserted into the Italian civil code in 2006 and of other more specific forms of patrimony like the Spanish regulacion del patrimonio protegido par las personas con discapacidad approved in 2003 and devoted to the economic protection of people affected by disabilities, ${ }^{13}$ or to the San Marino contratto di affidamento fiduciario by which a person manages another person's patrimony, in the interest of a third person with the effect that the patrimonial assets, submitted to his management, do not overlap with his own patrimonial assets.

These legal innovations are characterised by a common feature: to favour the separation of general patrimony of a person, in a manner which is possible for the same person to hold different patrimonial assets, each one finalised to the satisfaction of a specific economic

droit (Rosseau, 1995).

${ }^{10}$ See R Gary, Les notions d'universalité de fait e d'universalitè de droit (Sirey, 1932) 303; R Schmidt, Burgerliches Recht (Allgemeiner Teil, 1952); H Lange, Sachenrecht, (Tubingen, 1967) 38-42; J Carbonnier, Droit civil (Paris, 1967) 70; N Coviello, Manuale di diritto civile, (Società editrice libraria, 1929) 252; P Rescigno, Manuale di diritto privato italiano, (Utet, 1977) 442.

${ }^{11}$ See G Bellargent, 'L'introduction de la fiducie en droit francais par la loi du 19 fevrier 2007' (2007) 58 Revue juridique de l'économie publique 359; Y Emerich, 'Les fondements conceptuels de la fiducie française face au trust de la common law: entre droit des contrats et droit des biens' (2009) 1 Revue internationale de droit comparé 49.

${ }^{12}$ See G Peroni, "La norma di cui all'art. 2645-ter: nuovi spunti di riflessione in tema di trust" (2006) 20 Diritto del Commercio Internazionale 575; A Morace Pinelli, Atti di destinazione, trust e responsabilità del debitore (Giuffrè, 2007); F La Rosa, Patrimoni e finanziamenti destinati ad uno specifico affare: ottica destinazione, ottica separazione; analisi delle prospettive di sviluppo e dei profili di rischio connessi ai nuovi strumenti di federalismo patrimoniale finanziario (Giuffrè, 2007); M Indolfi, Attività ed effetto nella destinazione dei beni, (Giuffrè, 2010); M Astone Destinazione di beni allo scopo: fattispecie ed effetti (Giuffrè, 2010).

${ }^{13}$ See M M Azcano, El patrimonio protegido de las personas con discapacidad: aspectos civiles, (La Ley, 2011); P E Tortajada, El patrimonio protegido de las personas con discapacidad, (Tirant lo Blanch, 2012); A Quesada Sanchez, "El discapacidado y su patrimonio protegido" (2008) 75 Revista del Ministerio de Trabajo y Asunto Sociales 187. 
interest. It follows that the traditional function of guarantee recognised to patrimony is destined to change.

In fact, on assets that form that specific patrimony, only those who result to be creditors against the holder of said specific assets (by virtue of assumed obligations for the realization of the specific aim to which those assets are intended) can be satisfied. In other words, the guaranteed function is not only limited to a restricted group of creditors but, at the same time, specifically oriented to the satisfaction of specific interests, appreciated by the legal order, such as those described before. It happens, independently, from the traditional function of recognized patrimony: to guarantee the creditors of its holder, in the event of the nonperformance of an obligation or of other breaches of legal duty. This approach clearly shows the opening of the continental legal orders to the cited dynamic vision about the management of patrimonial assets, no longer inspired by a static conception of patrimony, for which a physical or legal person can be the holder of only one patrimony.

\section{The notion of patrimony according to the 'subjective' and 'objective' theories, their influence on civil law systems: a comparison with common law}

To understand the role that patrimony can perform within Private International Law according to the perspective of Civil Law, it is useful, first of all, to remember that it constitutes a system category and not a legislative category. In other words, patrimony does not receive a precise legislative notion by any rule contained in any legal order. This is usually a conscious decision of each lawmaker that prefers to delegate to doctrine and case law the task to develop, specify and integrate the above definition. In this way, each legal system acquires more flexibility adapting itself to new concepts and requirements emerging as time elapses. The so called subjective theory, elaborated by Aubry and Rau, had a significant success in defining patrimony These scholars, in their handbook Le Cour de droit civil francais, clearly affirmed :

l'idée de patrimoine se déduit directement de celle de la personnalitè... le patrimoine est, en principe, un et indivisible comme la personnalité meme...le patrimoine est l'émanation de la personalité et l'expression de la puissance juridique dont une personne se trouve investie comme telle. ${ }^{14}$

\footnotetext{
${ }^{14}$ See Aubry and Rau supra n 9, 133.
} 
In a nutshell, according to Aubry and Rau's theory, patrimony may be defined as the set of legal relations (assets and liabilities) of economic relevance belonging to a particular person or entity. Thus, patrimony is a manifestation of the legal personality of every legal subject within the world of economic relations. In these terms, the principle of unity that inspires the subjective theory finds a full realisation, thanks, above all, to the identification of patrimony with the person of its holder.

On the basis of the subsequent developments that have influenced the subjective theory other scholars ${ }^{15}$ have made important conclusions. First, a patrimony without a holder is inconceivable and, at the same time, it is not plausible that the same person could possess more than one patrimony. Second, patrimony, as a single entity, is transferable only mortis causa and not inter vivos (by contract of sale or any other negotiable instrument). This occurs essentially for two reasons: first, there is not, unlike what happens for contracts and credits, a general negotiable instrument by which it is possible to transfer patrimony from one person to another; second, the need to ensure the continuity of legal economic relations belonging to a person is usually considered with regard only to the event of the death of a person or his bankruptcy.

The theory in question has succeeded in having a fundamental influence on the development of legal culture, in many civil law countries, regarding the complex discipline of patrimony. This is true, even if the subjective theory has been contradicted by some positive law provisions, in particular those relating to vacant succession ${ }^{16}$ and inheritance with benefit of inventory ${ }^{17}$ from which we get the admissibility of the existence of patrimonial assets without a specific individual holder. In other words, the separation of patrimonial assets is not absolutely prohibited in civil law systems, even if only in specific and exceptional circumstances, strictly defined by each national legislator. Consequently, individuals are not allowed to create different forms of separate patrimonies, apart from those mentioned, at the

${ }^{15}$ See F Galgano, "Struttura logica e contenuto normativo del concetto di persona giuridica", (1965) 5 Rivista di diritto civile 553; E J Cohen, C Simitis, "Lifting the veil in the company laws of European continent" (1963) 12 International and Comparative Law Quaterly 183; A Seriaux, "La notion juridique du patrimoine. Breves notations civilistes sur le verbe avoir » (1994) 93 Reveu Trimestrelle de Droit Civile 801; J A Doral Garcia, "El patrimonio como instrumento tecnico juridico" (1983) 36 Anuario de derecho civil 1269.

${ }^{16}$ The vacant succession makes reference to succession where an estate has suffered failure. A vacant succession occurs not only when an estate is vacant, but also when an heir having possession of an estate refuses to administer it. Vacant successions are administered by legal representatives and they are known as administrators of vacant successions.

17 The benefit of inventory requires all executors or other administrators of the estate of a deceased to make an inventory of the estate and to pay all debts of the estate before distribution to the beneficiaries. It also gives them the opportunity of ascertaining the net value of the estate before accepting it. 
expense of their private autonomy.

However, at the present time, the more recent civil law doctrine, ${ }^{18}$ following the dynamic approach described before, considers that patrimony should not necessarily be identified with the person of its holder, nor be considered only as a unique legal entity, but rather it may articulate itself in different ways on the basis of the aim that the respective holder intends to pursue through the different ways in which his assets are held. This method is receiving particular attention in civil law systems, for example, through the introduction of the cited French contrat de fiducie ${ }^{19}$ and the Italian atto di destinazione. ${ }^{20}$ Thanks to these new legal concepts, we note a significant effect for which the unitary idea of patrimony, that is at the basis of the subjective and objective theories before analysed, in those systems, gives way, at least at their internal level, to a divisional approach in regards to the management of patrimony.

On the contrary, a different situation characterises common law systems in which we note the traditional absence of a unitary approach to patrimony. ${ }^{21}$ This is due, probably, to many reasons. First of all, in the English language there is not a specific word that designates the conceptual equivalent of Italian and Spanish Patrimonio or French Patrimoine or German Vermogen. In other words, English uses the expression 'patrimony' above all for convenience, but actually that word does not have the same meaning as in the civil law tradition. In fact, in this last case, it makes reference to all personal and real entitlements, including movable and immovable property, belonging to a natural or a legal person - a notion that, only partially, coincides with the common law concept of a person's estate.

This linguistic element is absolutely relevant, as the absence of an equivalent word

18 See L M Lo Puky, 'The Death of Liability' (1996) 106 Yale Law Journal 1; A M Patault, 'La personne morale d'une nationalisation à l'autre, naissance et mort d'une théorie' (1993) 17 Droits 79; F Santoro-Passarelli, Dottrine generali del diritto civile (Jovane, 1986) 85; S Guinchard, L'affectation des biens en droit privé français (L.G.D.I., 1976) 330.

${ }^{19}$ The French civil code defines the fiducie as a contract according which a settlor transfers all or part of its assets, rights or securities to a fiduciary that, in maintaining them separately from its own patrimoine, acts according to a specific objective for the benefit of its beneficiaries or the settlor itself. The fiducie amounts to a temporary transfer of ownership: the assets transferred to the fiduciary are no longer part of the settlor's assets. The latter loses any right of ownership with regard to those assets. The only remaining right is a "droit personnel de bonne exécution du contrat de fiducie" a contractual duty set out in the contract itself. The assets affected to the fiducie enter the fiduciary's patrimoine, in which they will constitute a distinct pool of assets.

20 This legal institute is included in the Art 2645 ter of the Italian civil code and it is similar to the contract of fiducie even if the Italian legislator never uses the word fiducie or other linguistic term that can make direct reference to the experience of a trust. By the atto of destinazione, the settlor establishes the bond of destination engraved on goods, in order to achieve an interest worthy of protection, leading to segregated liability.

${ }^{21}$ In these terms see L Smith, "Trust and patrimony" (2009) 28 Estates, Trusts and Pensions Journal 332; G. Gretton, 'Trust and Patrimony', in H MacQueen (ed), Scots Law into the 21 $1^{\text {st }}$ Century: Essays in Honour of W A Wilson (Sweet and Maxwell, 1996) 182. 
represents an index expressing a different thought about the legal category in question that is inevitably the result of another social and cultural vision. Traditionally, in fact, the AngloSaxon system is influenced by a liberal and pragmatic approach, ${ }^{22}$ including the way law is typically conceived, ie where everything that is not forbidden is possible. ${ }^{23}$

Through the establishment and wide use of $\operatorname{trusts}^{24}$ in common law systems the idea has spread that it is possible to conceive 'in the hands' of a person not only a general patrimony, but many and different 'pools' of assets, each one with its own legal autonomy and regulation.

\section{The unitary vision of patrimony and conflict of laws in civil law countries}

In the previous paragraphs, we have observed how, in civil law systems, the principle of unity has inspired, for a long period, the regulation of patrimonial assets. At the same time, we have underlined how at the roots of the principle of unity there is a static vision of patrimony closely dependent on guaranteeing the generality of creditors of the holder, in the event of the non-performance of an obligation, or of other breaches of legal duty.

However, the principle of unity has played a different and plainer role as regards to the regulation that patrimony traditionally receives at the level of national rules characterising PIL of civil systems. In the context of the PIL of succession civil law countries have usually adopted a unitarian approach which states that the law of succession is the law of the deceased's citizenship or habitual residence and that a single legal system governs the worldwide estate.

\footnotetext{
${ }^{22}$ The emphasis on pragmatism has deep cultural roots. Particularly, some authors suggest this relates to the fact that Britain has never been subject to the kinds of external constraints which have resulted in a more rationalist approach to politics in other countries. For example, Britain has never had to justify its political system from 'first principles' like the American founding fathers or rebuild its constitutional framework following defeat in war as Germany had to do following the Second World War. See G Gutting, Pragmatic liberalism and the critique of modernity (Cambridge University Press, 1999).

${ }^{23}$ See A V Dicey, Lectures on the Relation between Law and Public Opinion in England during the Nineteenth Century (Liberty Fund, 2008); P Birks, "Adjudication and Interpretation in the Common Law: A Century of Change", (1994) 14 Legal Studies 156; J Beatson, "Has the Common Law a Future?" (1997) 56 The Cambridge Law Journal 291; M Hale, History of Common law in England (University Press of Chicago, 1971).

24 On the origins of trusts and its evolution see J Story, Commentaries on equity Jurisprudence (Sweet \& Maxwell,1920) 393; M A Badre, Le developpement historique des uses jusq'à l'introduction du trust en droit anglis (Rousseau,1932) 13; F W Maitland, Equity. A Course of Lectures (Cambridge, 1936) 23; C Hamson and T Plucknett, The English Trial and Comparative Law (Cambridge University Press, 1952); M Lupoi, Appunti sulla real proprerty e sul trust nel diritto inglese (Giuffrè, 1971), W F Fratcher, "Trust", in International Encyclopedia of Comparative Law, Property and Trust (Tubingen, 1973) 84.
} 
This unified solution, however, does not exclude the application of other conflict of laws; this may happen, in particular, with regard to the case of real estate for which it will often be necessary to make reference to the lex situs to fulfil the publicity requirements required by the land register connected to the acquisition of immovable property that is part of the inheritance.

On this specific aspect, we can note how, in particular, Italian, Spanish, German, Austrian and Dutch national systems of international private law have resorted to the principle of unity by which questions relating to intestacy or wills are governed by one single law, namely the personal law of the deceased, even before the recent adoption of the EU Succession Regulation (650/2012) which affirmed the unity principle.

In common law systems, succession matters are submitted to the principle of scission. As a consequence, the destination of movables on the death of the owner is governed by the law of his domicile, whilst the destination of immovables is governed by the law of the situs. Consequently, the immovable estate of the deceased is divided up according to where the immovable is situated and distributed according to the various leges situum.

From what we have said so far, it results that, within civil law systems, there is a discrepancy between substantive and internal PIL rules about the regulation of patrimony. In PIL patrimony, with the exception of succession and insolvency that adhere to the principle of unity, falls under the principle of divisibility. In PIL, patrimony continues to be considered according to its singular elements: movable, immovable, torts and contracts; each one subject to its own specific PIL rules.

\section{E. Trusts: A possible contact point between unitary and divisional approaches in the management of patrimony?}

Briefly, it is important to remember that a trust has many important features. This is true, in particular, in cases where the property holder is a fiduciary who must have full title to the property under administration as opposed to some lesser right, such as possession, detention or factual control. The fiduciary has full title or the ability to take full title of trust property only when that property is free from the claims of the trustee's personal creditors. The last point depends on the fact that, on the basis of an in rem characterisation of his rights or of his entitlement to reinstate the trust, the beneficiary is able to trace the trust property into the hands of a false trustee or into the hands of a third party.

From these brief evaluations, we can understand how in common law systems, a trust has 
the intrinsic capacity 'to break the right of property', in the so-called dual ownership (the ownership of the trustee and the ownership of the beneficiary), while in civil law, owing to the numerus clausus of rights in $\mathrm{rem}^{25}$ property is traditionally considered as a unique legal entity. Thanks to this, in common law countries, a trust allows the creation of different patrimonial assets held by the same person, each one devoted to the realisation of a specific aim.

This is an effect of the dynamic vision of patrimony, examined previously, that is at the basis of trust and its different uses in Anglo-Saxon systems. But, while the dynamic idea of patrimony inspired common law systems from the institution of trust in the Middle Ages, the opening of civil law to this vision is recent and is due to various reasons.

First, due to the phenomenon of economic and trade globalization we can see tough competition amongst States in attracting foreign direct investments. In fact, only a legal system capable of admitting different forms of segregation of assets can be attractive for investors, usually worried about losing their money from the attack of creditors of the holders of the patrimony in question.

Second, thanks to the adoption in 1985 of the Hague Trusts Convention ${ }^{26}$ this concept cam eto the attention of those countries where the trust concept was unfamiliar.

Third, in 1989 the EU adopted Directive 667 on single-member private limited-liability companies. ${ }^{27}$ By this act, the EU, for the first time, stated it was important "to provide a legal instrument allowing the limitation of liability of the individual entrepreneur throughout the Community, without prejudice to the laws of the Member States which, in exceptional circumstances, require that entrepreneur to be liable for the obligations of his undertaking." In other words, it becomes admissible for a company to "have a sole member when it is formed and also when all its shares come to be held by a single person (single-member company). "28 So, from that moment the individual entrepreneur has the capacity to separate the fate of their personal assets from that relating to their individual business.

From that time, we note the adoption within EU legal systems of rules created to admit different forms of patrimony, usually devoted to the realisation of a specific aim and

\footnotetext{
${ }^{25}$ It is a principle present in most part of civil law countries which implies that one may only create rights in rem which fall within one of the types already prescribed by the law.

${ }^{26}$ See supra $\mathrm{n} 7$.

${ }^{27}$ Directive 89/667/EEC [1989] OJ L395/40.

${ }^{28}$ See Art 2 of the Directive.
} 
characterised by the creation of a segregation of patrimonial assets belonging to the same subject: this is the case of the quoted French contrat de fiducie, the Italian atto di destinazione or the Spanish acto costitutivo del patrimonio protegido par las personas con discapacidad. In truth, all these legal concepts represent, at the internal level, sui generis forms of trust. ${ }^{29}$ In other terms, these are legal instruments that have been designed by civil law countries to make their legal systems more competitive and attractive for foreign investors within the socalled market of legal rules ${ }^{30}$ where usually the Anglo-Saxon system stands out for its versatility making London, despite Brexit, the financial capital of Europe.

So, thanks to the recourse to the trust, we gather instead the opportunity to submit patrimony, at PIL level, to a unitary discipline by virtue of the Hague Convention of 1985. In fact, this international instrument allows settlors to put forward all their patrimonial assets under only one law, including the case where the settlor holds the function of trustee and also the role of beneficiary. In these terms, in order to identify the applicable law, we have to consider particularly Article 6 of the Convention, according to which: "A trust shall be governed by the law chosen by the settlor. The choice must be express or be implied in the terms of the instrument creating or the writing evidencing the trust, interpreted, if necessary, in the light of the circumstances of the case."

However, the recourse to trusts in civil law systems for submitting patrimony to a unitary governance at the PIL level presents some limits and obstacles. The Hague Trusts Convention is in force for only 14 States, ${ }^{31}$ with the effect that the idea of giving form to a figure of international trust is likely to remain a 'dead letter' in many civil law States.

Secondly, according to its Article 4, the Hague Convention does not apply to preliminary issues relating to the validity of wills or of other acts by virtue of which assets are transferred by the settlor to the trustee. In this way, the profiles concerning the validity of the acts by which the trust is established and the transfer of assets to the trust is made, shall be submitted to the law of the State of the competent court. This inevitably involves a coordination between the law applicable to the act by which it achieves the transfer of assets to the proper law of the trust identified on the basis of the rules established by the Convention.

29 Because, as the trust, they create a separate patrimony both with reference to that of the settlor, both administrator and beneficiary.

${ }^{30}$ See supra note $\mathrm{n} 5$.

31 Australia, Canada, China (Hong Kong only), Cyprus, Italy, Luxembourg, Liechtenstein, Malta, Monaco, the Netherlands, Panama, San Marino, Switzerland and United Kingdom. 
So, it is not possible to operate an absorption of preliminary issues ${ }^{32}$ within the law applicable to the trust, with the effect that the institution of trust and the possible reconstruction of patrimony in unified terms can be frustrated.

\section{F. Conclusion}

In civil law systems the meaning of patrimony as a legal concept is contested. The doctrine was traditionally influenced by the followers of the unitary and static approach and more recently by a divisional and dynamic approach in the regulation of patrimonial assets. These different approaches to the concept of patrimony have had significant effects on its regulation in internal law and in PIL: substantive law largely unitary and PIL largely divisional.

However, recent regulatory changes to substantive rules in some continental countries favoured the rise at internal level of a divisional method due to a dynamic conception of patrimony with the effect that any person (natural or legal entity) may be a holder of various patrimonial assets and not just a single patrimony. But, this phenomenon does not preclude the possibility of bringing patrimony to a unitary regulation both at the level of internal substantive rules and PIL, thanks to the use of trusts in accordance with the Hague Convention.

It could be useful to classify PIL rules on patrimony according to a single criterion in order to overcome the different positions previously described with reference to the management of patrimony.

The recourse to the criterion of the domicile of the holder of patrimony could be the optimal olution. ${ }^{33}$ Domicile is the place where a person has his/her principal residence to which he/she returns or intends to return in order to manage his/her patrimonial assets and serves to reveal a close and stable connection with a legal order.

Obviously, the aim to identify at PIL level a uniform regulation of patrimony according to the criterion of domicile is difficult to realise. Essentially, it is due to the absence of a uniform

\footnotetext{
32 As we know, determining and solving the preliminary question is often necessary to resolve the principal question. In an international context, one can apply the lex fori's or the lex causae's PIL to determine the law applicable to the preliminary question. Traditional advantages of the lex causae approach lose their cogency in the EU context, the deterrence of forum shopping, the presumption of the closer connection and the international harmony. On the other hand, many traditional and new reasons support the lex fori approach: national harmony, foreseeability, practicability and further integration. See S Goessl, "Preliminary Questions in EU Private International Law" (2012) 8 Journal of Private International Law 63.

${ }^{33}$ Domicile is what is termed in PIL as a connecting factor which connects an individual with a system of law for the purposes of determining a range of matters, principally related to his status or property.
} 
concept of domicile in a number of legal systems (to civil lawyers in Europe who do not apply common law, it means essentially habitual residence, while at common law it is a fairly complicated legal concept linked largely to where a person intends to live indefinitely) and the traditional resistence of States to give up control of the economic sphere of their citizens and firms. Nonetheless, an extension of the use of the domicile criterion could have a significant benefit in terms of legal certainty and predictability of the legal results.

So, while waiting for the standardising of as much as possible of the various systems of PIL according to the domicile criterion, the technique through which a shared regulatory system in the governance of patrimony could be achieved, might be represented by the socalled method of harmonisation. ${ }^{34}$ This means the use of connecting factors characterising a particular legal matter in their intrinsic reasonableness. In other words, according to this scheme, every legal issue in private law should be governed by the law of the place or country with which the issue is most closely connected. That, in this context, suggests taking into account the traditional function of patrimony: to guarantee the holder's creditors according to the principle of non-discrimination ${ }^{35}$ on the basis of their nationality.

This option is probably the best solution, in the absence of a global legal system inspired by domicile. Considering that harmonisation, although it is not at all synonymous with unification, ${ }^{36}$ is a method capable of coordinating the different private law systems in the

34 The cited method has its roots in the theory of Savigny (1779-1861). In his most famous book, System des heutigen römischenRechts (System of Modern Roman Law), published in 1849, he asserted that a legal issue in private law should be governed by the law of the place or country with which the issue is most closely connected. He called such place its principal place (Sitz) or home country. According to him, each community has its own private legal system based on its own value system, which is independent from the interests of the sovereign state. Therefore, we can apply an appropriate foreign private law to the problem at issue. In order for an issue to be dealt with appropriately, we should apply the law that has the closest connection with the issue, which is the law of the home country. If the same law is chosen to apply to issues in accordance with choice-oflaw rules in every country, the differences in the content of the laws of countries do not matter at all. In this way, Savigny's method can achieve the objective of private international law that is to bring order to a cross-border legal situation.

${ }^{35}$ The principle of non-discrimination is part of private international law that deals with choice of law. However the general principle of equality before the law may be tolerant towards multilateral conflict rules, but the position will be different where specific rules of non-discrimination are at stake or where the rules of PIL concerned have a substantive content. On this point, see K Lipstein, Harmonization of Private International Law by the E.E.C. (Institute of Advanced Legal Studies, 1978); P Kinsch, "Choice of Law Rules and the Prohibition of Discrimination Under the European Convention on Human Rights, Nederlands International Privaatrecht" (2011) 1 University of Luxembourg Law Working.

${ }^{36}$ There are conflicting opinions on the differences in meaning of the terms: harmonisation and unification. In any event, as we observed above, these expressions are not synonymous. Particularly, Goldstein clarified that the word harmonisation "... suggests a functional unification which, however, is less than textual unity" (see S Goldstein, On Comparing and Unifying Civil Procedural Systems, Butterworth Lectures 1994, (Butterworths, 1995) 28. With reference to the evolution of the term harmonisation in Private International Law, see P Borba Casella, "Economic Integration and Legal Harmonisation with Special Reference to Brasil" (1998) Uniform Law Review 287; A Rosett, "Unification, Harmonisation, Restatement, Codification and Reform in International Commercial Law" (1992) 40 
interests of justice and certainty for those involved in transnational activities or relationships, even if the satisfaction of said goals can be frustrated by divergences existing within the rules adopted in the different countries. 